\title{
DETECTION OF SOME PATHOGENIC BACTERIA IN RAW FARM MILK
}

\author{
Amira I. Moussa ${ }^{a}$, I. I. Alhawary ${ }^{b}$, Walaa M. Elkassas ${ }^{a}$ \\ ${ }^{\text {a }}$ Department of Food hygiene, Animal Health Research Institute, Egypt. \\ ${ }^{\mathrm{b}}$ Department of Food control, Kafrelsheikh university, Egypt.
}

\begin{abstract}
The objective of this study was performed to detect the incidence of Escherichia coli, Salmonella, Yersinia enterocolitica in raw farm milk samples. A total of 50 raw milk samples were collected from different dairy farms in Kafrelsheikh Governorate. The isolates were identified biochemically and serologically. The obtained results revealed that $E$. coli, Salmonella and Yersinia enterocolitica were detected in 32\%, $10 \%$ and $18 \%$, respectively. Additionally $50 \%$ of recovered E.coli were entero-hemorrhagic $\left(\mathrm{O}_{26}: \mathrm{H}_{11}\right.$ and $\left.\mathrm{O}_{111}: \mathrm{H}_{4}\right), 12.5 \%$ were entero-

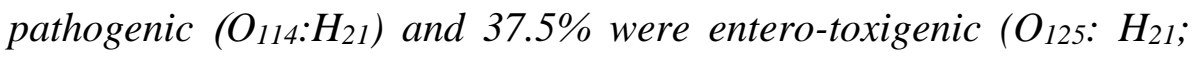

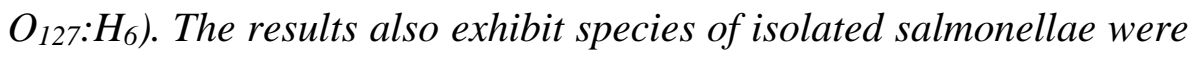
S.typhimurium (40\%), S. enteritidis were 60\% .The public health significance of isolated strains as well as suggested control measures were discussed to obtain high quality milk and healthy for human being .
\end{abstract}

Keywords: Farm milk, E. coli, Salmonella, Y. enterocolitica.

\section{INTRODUCTION}

Milk ranks high among other foods and is considered as the most perfect food for human from birth to senility as it is not only has good sensory properties and all nutrients required for the body for rapid growth but also could prevent or reduce risks of many nutritional deficiency diseases (Kalkwarf et al., 2003 and Marshall et al., 2003). 
Raw milk is still used by large number of farm families and workers and by a growing segment of the general population who believe that the milk is not only safe but also imparts beneficial health effects that are destroyed by pasteurization (Lejeune and Rajala-Schultz, 2009).

Milk and products derived from milk can harbor a variety of microorganisms and can be important sources of food borne pathogens. The presence of food borne pathogens in milk may be due to direct contact with contaminated sources in the dairy farm environment and to excretion from the udder of an infected animal. The bacteria can access to the milk through colonization of the teat canal or an infected udder (clinical and sub clinical mastitis) or gets contaminated from milk utensils and water supply used (Gruetzmacher and Bradle, 1999 and Hayes et al., 2001).

The presence of bacteria in milk has many undesirable effects on the quality and safety of milk and its products (Szteyn et al., 2005) and the milk becomes unsuitable for further processing (Nanu et al., 2007). Raw milk is usually colonized by a variety of pathogens such as Enterohaemorrhgic E.coli, Staph. aureus, S. typhimurium and Y. enterocolitica, which considered as a public health hazard (Marco and Wells-Bennik, 2008).

E.coli is a normal inhabitant of intestine of animals and humans but its recovery from food may be of public health concern due to the possible presence of entero-pathogenic and/or toxigenic strains which lead to sever gastro-intestinal disturbance (Soomro et al., 2002). E.coli is among many pathogenic microorganisms which can access to milk and some of dairy products (Quinn et al., 1994) which considered a reliable indicator of contamination by manure, soil and contaminated water (Todar, 2008). 
Milk and milk products have been identified as the vehicle for transmission in approximately $5 \%$ of salmonellosis cases $(C D C, 2000)$. Contamination of raw milk with Salmonella spp is mostly due to infected persons and contamination of the environment, since natural infections of the udder are rare and seldom contribute to human food poisoning (Mubarak et al., 2010).

$Y$. enterocolitica is rapidly worldwide as enteric pathogen and has become major cause of diarrhea. Since the natural reservoir of $Y$. enterocolitica infection was latent infection in the intestinal tract of wild and domestic animals. The main source of contamination of raw milk with $Y$. enterocolitica was not mammary gland but probably feces (Quinn et al., 1994).

Therefore this study was carried out to determine the prevalence of some pathogenic bacteria spread by contamination of raw milk. The public health significance of the isolated microorganisms was discussed and suggests control and preventive measures.

\section{MATERIALS AND METHODS}

\section{Collection of samples:}

A total of 50 raw farm milk samples were collected randomly from different dairy farms in Kafrelsheikh Governorate, Egypt. Milk samples were transferred directly to the laboratory with a minimum of delay, where they prepared for examination.

Isolation of Escherichia coli according to (Atlas et al., 1995).

Isolation of Salmonella as recommended by (ISO 6579: 2002).

Isolation of Yersinia enterocolitica according to (Schieman, 1982) and ( Walker and Glimour, 1986). 


\section{RESULTS}

Table (1): Incidence of isolated pathogens from examined raw farm milk samples:

\begin{tabular}{|c|c|c|c|}
\hline \multirow{2}{*}{ Pathogen } & \multirow{2}{*}{ No. of examined samples } & \multicolumn{2}{|c|}{ Positive samples } \\
\hline & & No. & $\%$ \\
\hline Escherichia coli & 50 & 16 & 32 \\
\hline Salmonella spp & 50 & 5 & 10 \\
\hline Yersinia enterocolitica & 50 & 9 & 18 \\
\hline
\end{tabular}

Table (2): Serological identification of E.coli isolates:

\begin{tabular}{|c|c|c|c|c|c|}
\hline \multirow{2}{*}{$\begin{array}{c}\text { Strain } \\
\text { characteristics }\end{array}$} & \multicolumn{2}{|c|}{ Positive samples } & \multirow{2}{*}{$\begin{array}{c}\text { E.coli } \\
\text { strains }\end{array}$} & \multirow[t]{2}{*}{ No. } & \multirow{2}{*}{$\begin{array}{l}\% \text { from } \\
\text { the +ve } \\
\text { samples }\end{array}$} \\
\hline & No. & $\%$ from the +ve samples & & & \\
\hline \multirow{2}{*}{ EHEC } & \multirow{2}{*}{8} & \multirow{2}{*}{50} & $\mathrm{O}_{26}: \mathrm{H}_{11}$ & 4 & 50 \\
\hline & & & $\mathrm{O}_{111}: \mathrm{H}_{4}$ & 4 & 50 \\
\hline EPEC & 2 & 12.5 & $\mathrm{O}_{114}: \mathrm{H}_{21}$ & 2 & 100 \\
\hline \multirow{2}{*}{ ETEC } & \multirow{2}{*}{6} & \multirow{2}{*}{37.5} & $\mathrm{O}_{125}: \mathrm{H}_{21}$ & 3 & 50 \\
\hline & & & $\mathrm{O}_{127}: \mathrm{H}_{6}$ & 3 & 50 \\
\hline
\end{tabular}

Table (3): Serological identification of Salmonellae isolates:

\begin{tabular}{|c|c|c|c|c|}
\hline \multirow[b]{2}{*}{ Type of isolates } & \multicolumn{2}{|c|}{ Positive samples } & \multicolumn{2}{|c|}{ Antigenic structure } \\
\hline & No & $\%$ from+ve samples & $\mathbf{O}$ & $\mathbf{H}$ \\
\hline S.Typhimurium & 2 & 40 & $1,4,5,12$ & $\mathrm{i}: 1,2$ \\
\hline S.Enteritidis & 3 & 60 & $1,9,12$ & $\mathrm{~g}, \mathrm{~m}: 1,7$ \\
\hline
\end{tabular}

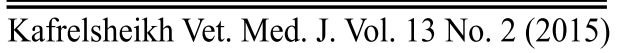




\section{DISCUSSION}

Raw milk is considered a high risk food as it is highly nutritious and serves as an ideal medium for bacterial growth. Several factors contribute to milk contamination such as poor hygienic milking conditions, contaminated equipment, milking utensils and poor personal hygiene.

Pathogenic bacteria in milk have been a major factor for public health concern since the early days of the dairy industry. Many diseases are transmissible via milk products .Traditionally raw or unpasteurized milk has been a major vehicle for transmission of pathogens (Vasavada, 1988). Many microorganisms can get access to milk, among these, E.coli which is often used as a marker organism. Recovery and counting of E.coli is used a reliable indicator of fecal contamination and possible presence of entero-pathogenic and /or toxigenic microorganisms which constitute a public health hazard. Most of E.coli are harmless, but some known as pathogenic bacteria causing severe intestinal and extra intestinal diseases in human (James et al., 2004).

The results given in table (1) showed that E.coli was detected In 16 (32\%) of the examined farm milk samples. Our findings were nearly similar to those obtained by Abbas et al. (2013) while lower incidence results were reported by Mayada and Fatma (2013) and Merwad et al. (2014).

Our results disagreed with microbiological standards for milk (FAO/WHO, codex standard, 2000) in EU and US who stated that raw milk should be negative for E.coli. 
Table (2) showed the serological identification of isolated E.coli from raw farm milk samples belonged to serovars: $\mathrm{O}_{26}: \mathrm{H}_{11}$ and $\mathrm{O}_{111}: \mathrm{H}_{4}$ (EHEC) were 4 (50) \% for each; $\mathrm{O}_{114}: \mathrm{H}_{21}$ (EPEC) was $2(100 \%)$ and $\mathrm{O}_{125}: \mathrm{H}_{21}$ and $\mathrm{O}_{127}: \mathrm{H}_{6}($ ETEC) were $3(50 \%)$ for each.

Serotypes like $\mathrm{O}_{26}$ has been found to be associated with infantile diarrhea among neonates and adult human patients suffering from gastroenteritis as reported by (Nishikawa et al., 2002).Thus these serotypes may be of zoonotic importance.

The public health importance of isolated Entero-pathogenic serovars had been attributed to its enterotoxin, which is implicated in causing gastro enteritis, epidemic children diarrhea, and sporadic diarrhea in children as well as food poisoning (Hassan and Afify, 2007), the recurrent outbreaks of life threatening human infections were attributed to STEC / EPEC contaminate milk and milk products (Martin and Beutin, 2011).

A high percentage of human salmonellosis occurs through the consumption of raw milk or dairy products manufactured with raw milk (CDC, 2003).

The results achieved in table (1) revealed that incidence of salmonella in the examined farm raw milk samples was $5(10 \%)$. lower findings were obtained by Hassan et al. (2000) and Tajbakhsh et al. (2012). On the other hand Ekici et al. (2004), Mhone et al. (2012) and Zeinhom and Gihan (2014) failed to detect any salmonella from examined raw milk samples. 
Our results were disagreed with Egyptian standard of raw milk (Es, 154/1/2005) which stated that raw milk should be free from salmonella spp. and microbiological standards for milk (FAO/WHO, codex standard, 2000) in EU and US stated that raw milk should be negative for salmonella spp.

Salmonellosis is one of the most important zoonotic bacterial pathogen of food-borne infection all over the world. The most important serotypes of salmonella are S. typhimurium and S. enteritidis (Fashae et al., 2010 and Hendriksen et al., 2011). Salmonella spp. can cause gastrointestinal disease. The main sources of transmission are water, eggs and raw foods (Karns et al., 2005).

The results given in table (3) show the incidence of salmonella serotypes in the examined samples were S. typhimurium $2(40 \%)$ and $S$. enteritidis $3(60 \%)$. It is noticed that $S$. enteritidis was the most prevalent isolated salmonella serotypes from examined raw milk samples, followed by $S$. typhimurium and this gradual prevalence reported by (Niaid, 2000).

Table (3) revealed that the antigenic structure of isolated salmonellae from the examined milk samples were $S$. typhimurium $(\mathrm{O}$ strain,1.4.5.12), (H strain,i:1,2); S.enteritidis (O strain 1,9,12), (H strain $\mathrm{g}, \mathrm{m}: 1,7)$.

$Y$. enterocolitica is the most common agent of genus Yersinia that is associated with a spectrum of clinical syndromes in man, with gastroenteritis as the most frequently encountered manifestation. Most cases are sporadic or occur in small clusters, but large outbreaks have been reported worldwide in families, schools, hospitals, and in association with community gatherings (Leclercq et al., 2005). 
Table (1) revealed that the incidence of Y.enterocolitica in examined raw farm milk samples was 9 (18\%). Lower incidence was reported by Hanifian and Khani (2012) and Sarah (2014) while higher results reported by Bernardino et al. (2013). On contrast Zeinhom and Gihan (2014) failed to detect Y.enterocolitica in examined milk samples.

The previously our obtained results were disagreed with Egyptian standards of raw cows milk (ES, $154 / 1 / 2005)$ that stated that raw milk should be free from Y.enterocolitica and microbiological standards for milk (FAO/WHO, codex-standard, 2000) in EU and US that stated that raw milk should be negative for Y.enterocolitica.

In other words, in regions in which dairy herds have been bred in small traditional farms rather than industrial ones and been milked by hand rather than by milking machine, the occurrence of Y.enterocolitica was higher. Probably milk could get contaminated with animal feces during the milking process in which contamination rate depend on hygienic practices prior and during milking (Hanifian and Khani, 2012).

Fredriksson and Korkeala (2003) stated that Y.enterocolitica has been isolated most frequently in temperate areas of the world and the majority of cases being reported from cooler regions of Europe and North America .The incidence of Y.enterocolitica organisms were much higher during winter than summer seasons (Toora et al., 1989).

\section{Conclusion and Recommendations:}

The results obtained in our study showed that presence of pathogenic bacteria such as E.coli, Salmonella spp. and $Y$. enterocolitica in milk, this suggests that raw milk should be considered as a vehicle for transmission of potentially pathogenic bacteria. Since a lot of people still 
drink raw milk especially in rural areas, this emphasis the need for educational efforts to improve dairy farmers'awareness of milk borne zoonoses, how these pathogens transmitted to milk, risk factors associated with milk borne pathogens and how to obtain fresh clean milk.

For achieving good quality milk produced within the dairy farm, some hygienic steps should be taken in consideration such as application of some hygienic practices during milking routine such as cleanliness of animal's udder and teats and diseased animals should be isolated. Cleanliness of milker's hands and also he should wear clean clothes and head cap were very efficient in improving milk quality and control of zoonotic diseases. Also diseased persons must not come in contact with animals.

All equipment come in contact with milk should be efficiently clean and sterile. The use of refrigeration during processing, storage and handling of the milk and dairy products are also essential.

\section{REFERENCES}

- Abbas, M.N.; Khattak, B.; Sajid, A.; Islam1, T.U.; Jamal, Q. and Munir, S. (2013): Biochemical and bacteriological analysis of cows' milk samples Collected from district Peshawar. Int. J. Pharm. Sci. Rev. Res., 21(2), 40: 221.

- Atlas, R.M.; Parks, L.C. and Brown, A.E. (1995): Laboratory manual of Experimental Microbiology. Mosby. New York. 108- 110.

- Bernardino, V.L.; Quiñones, R.E.I.; Fernández, F.J. and Vázquez, S.C. (2013): Prevalence of Yersinia enterocolitica in raw cow's milk collected from stables of Mexico City. J. Food Prot.; 76(4): 694-8. 
- CDC (Center for Disease Control) (2000): Surveillance for foodborne-disease outbreaks-United States, 1993-1997. Morb. Mortal. Wkly. Rep. 49(Surveillance Summary-1):1-64.

- CDC (Center for Disease Control) (2003): Multistate outbreak of Salmonella serotype Typhimurium infections associated with drinking unpasteurized milk- Illinois,Indiana, Ohio, and Tennessee. MMWR; 52:613.

- ES, Egyptian Standard (2005): Egyptian Organization for Standardization and Quality control. Raw milk the part 1. ES:154/1/2005.

- Ekici, K.; Bozkurt, H. and Isleyici, O. (2004): Isolation of some pathogens from raw milk of different MilchAnimals.Pakistan .J. of Nutrition 3(3):161-162.

- FAO/WHO (Food and Agriculture Organization/World Health Organization) Codex Standard (2000): Microbiological Standards for Milk (Alimentarius Commission, 26 ${ }^{\text {th }}$ Session, Report of the 5th session of the Codex Committee on milk and milk products. Draft Revised Standard for Fermented milks.

- Fashae, K.; Ogunsola, F.; Aarestrup, F.M. and Hendriksen, R.S. (2010): Antimicrobial susceptibility and serovars of Salmonella from chickens and humans in Ibadan, Nigeria. J. Inf. Dev. Count; 4:484-94.

- Fredriksson, A.M. and Korkeala, H. (2003): Molecular epidemiology of Yersinia enterocolitica 4/O: 3. Advances in Experimental Medicine and Biology, 529: 295-302. 
- Gruetzmacher, T.J. and Bradle, R.L.J. (1999): Identification and control of processing variables that affect the quality and safety of fluid milk. J. Food Prot. 62:625-631.

- Hanifian, S. and Khani, S. (2012): Prevalence of virylent Yersinia enterocolitica in bulk raw milk and retail cheese in Northen- West of Iran. International .J. of Food Microbiology.155:89-92.

- Hassan, G.M. and Afify, S.H. (2007): Occurrence of some pathogenic microorganisms in kareish cheese and their public health significance. BS Vet. Med. J. $5^{\text {th }}$ Sci. Conf.:142-50.

- Hassan, L.; Mohammed, H.O; McDonough, P.L. and Gonzalez, R.N. (2000): A cross-sectional study on the prevalence of Listeria monocytogenes and Salmonella in New York dairy herds. J. Dairy Sci., 83:2441-2447.

- Hayes, M.C; Ralyea, R.D; Murphy, S.C.; Carey, N.R.; Scarlett, J.M.; et al. (2001): Identification and characterization of elevated microbial counts in bulk tank raw milk. J. Dairy Sci. 84:292-298.

- Hendriksen, R. S.; Vieira, A.R .; Karlsmose, S.; Lo Fo Wong, D. M.; Jensen, A.B. and Wegener, H.C.; et al. (2011): Global monitoring of Salmonella serovar distribution from the world health organization global food borne infections network country data bank: results of quality assured laboratories from 2001 to2007. Food Borne Path. Dis. 8(8):1-14.

- ISO (6579:2002): Microbiology of food and animal feeding stuffs Horizontal method for the detection of Salmonella spp. 
- James, Kaper, J.B.; Nataro, J.P. and Mobley, H.L. (2004): Pathogenic E. coli. Nat. Rev. Microbiol. 2: 123-140.

- Karns, J.S.; Van Kassel, J.S.; McKluskey, B.J. and Perdu, M. (2005): Prevalence of Salmonella entric in bulk tank milk from US dairies as determined by polymerase chain reaction. J. Dairy Sci. $88: 3475-9$.

- Kalkwarf,H.J.; Khoury, J.C. and Lanphear, B.P.(2003): Milk intake during childhood and adoulescence, adult borne denist and osteoporotic fracture in uswomen. Am. J. Clin.Nutr. 77(1):10-1.

- Leclercq, A.; Martin, L.; Vergnes, M.; Ounnoughene, N.; Laran, J. and Giraud, P. et al. (2005): Fatal Yersinia enterocolitica biotype 4 Serovar O:3 sepsis after red blood cell transfusion. Transfusion. 45: 814-8.

- Lejeune, J.T. and Rajala -Schultz, P.J. (2009): Food safety: Unpasteurized milk: a continued public health threat. Clin. Infect. Dis. 48: 93-100.

- Marco, M.L. and Wells- Bennik, M. (2008): Impact of bacteriological genomics on determining quality and safety in the dairy production chain. Int. Dairy J. 18: 486-495.

- Marshall, T.A.; Levy, S.M.; Broffit, B.; Warren, J.J.; EichenbergerGlimore, J.M. and Burns, T.L. et al. (2003): Dental caris and beverage consumption in young children.Pediatrics.112(3): 184-91. 
- Martin, A. and Beutin, L. (2011): Characteristics of shiga toxinproducing Escherichia coli from meat and milk products of different origins and association with food producing animals as main contamination sources. International .J. of Food Microbiology.146: 99-104.

- Mayada, M. Gwida and Fatma, A. El- Gohary (2013): Zoonotic bacterial pathogens isolated from raw milk with special reference to Escherichia coli and Staphylococcus aureus in Dakahlia Governorate. Egypt. 2:705 doi: 10.4172/scientific reports.705, Open Access Scientific Reports, volume 2, Issue 4, 1-4.

- Merwad, A.; Rasha, Gharieb and Taisir, Saber (2014): Occurrence of shiga toxin -producing Escherichia coli in lactating cows and in contact workers in Egypt: serotypes, virulence genes and zoonotic significance. Life Science .J. 11(5): 563-571.

- Mhone, T.A.; Matope, G. and Saidi, P.T. (2012): Detection of Salmonella spp., Candida albicans, Aspergillus spp. and antimicrobial residues in raw and processed cow milk from selected Smallholder Farms of Zimbabwe. Veterinary Medicine International. doi:10.1155/301902, 5 Pages.

- Mubarack, H.M.; Dhanabalan, R. and Balachander, S. (2010): Microbial quality of raw milk samples collected from different villages of Combatore District, Tamilhadu, South India, Indian J. of Sci. and Techn. 3 (1): 61-63. 
- Niaid (2000): National Institutes of Health U.S. Department of Health and Human Services Fact Sheet (Foodborne Disease), Office of Communication and Public Liaison.

- Nanu, E.; Latha, C.; Sunil, B. and Prejit T.M. et al. (2007): Quality assurance and public health safety of raw milk at the production point. Am. J. of Food Technology 2: 145-152.

- Nishikawa, Y.; Zhou, Z.; Hase, A.; Ogasawara, J.; Kitase, T.; Abe, N.; Nakamura, H.; Wada, T.; Ishii, E.; Haruki, K. and the Surveillance Team (2002): Diarrhea genic Escherichia coli isolated from stools of sporadic cases of diarrheal illness in Osaka city, Japan between 1997 and 2000: Prevalence of Entero aggregative E.coli heat stable enterotoxin 1 gene - possessing E. coli. Jpn. J. Infect. Dis. 55: 182-190.

- Quinn, P.J.; Carter, M.E.; Markey, B. and Carter, G.R. (1994): Clinical Veterinary Microbiology, Mosby, and Edinburgh. London, pp: 159-168.

- Sarah, A.M. (2014): Detection of some pathogenic organisms from dairy farm milk with special reference to Mycobacterium tuberculosis infection (bovine type). M.V.Sc. of Vet. Sci. Faculty of veterinary medicine, Alexandria.

- Schieman, D.A (1982): Development of a two-step enrichment procedure for recovery of Yersinia enterocolitica from food. Applied and Environmental Microbiology 43, 14- 27. 
- Soomro, A.H.; Arain, M.A.; Khaskheli, M. and Bhutto, B. (2002): Isolation of Escherichia coli from raw milk and milk products in relation to public health sold under market conditions at Tandojam. Pak. J. Nutr. 1:151-152.

- Szteyn, J.; Wiszniewska, A.; Fus- Szewczyk, M.M. and Cichosz, W. (2005): Changes in microbiological quality of raw milk from the region of Warmia and Mazuryin 1998-2003. Veterinar. jjair. Zoo. Technika. 32.

- Tajbakhsh, F.; Tajbakhsh, E.; Momeni, M.; Rahimi, E. and Sohrabi, R. (2012): Occurrence and antibiotic resistance of Salmonella spp isolated from raw cow's milk from Shahahrekord, Iran. Intl. J. Microbiology Res. 3 (3): 242-245.

- Todar,K.(2008): Pathogenic E.coli. Available on http://www.textbookof bacteriology. Net/e.coli.html.

- Toora, S.; Singh, G. and Tiwari, R.P. (1989): drug resistance and Lecithinase activity of Yersinia enterocolitica isolated from buffalo milk. International J. of Food Microbiology. 9 (3): 167-171.

- Vasavada, P.C. (1988): Pathogenic bacteria in milk-A review. J. Dairy Sci.71:2809-2816.

- Walker, S.J. and Gilmour, A. (1986): The incidence of Yersinia Enterocolitica like organism in raw pasteurized milk in Northern Ireland .J. Appl. Bacteriol. 61:133-136.

- Zeinhom, M.M.A. and Gihan, K. Abdel-Latef. (2014): Public health risk of some milk borne Pathogens. Beni-Suef University .J. of Basic Applied Science XXX(1-7). 


\section{الكثف عن بعض مسببات الأمر اض البكتيرية فى حليب المزارع الخام \\ أميرة إبراهيم موسى1، إبراهيم إبراهيم الهوارى، ولاء محمد القصاص11}

1 قسم صحة الأغذية ، معهل بحوث صحة الحيوان - فرع كفر الثيخ ، مصر

2 قسم مراقبة الأغذية ، كلية الطب البيطرى ، جامعة كفر الثيخ ، مصر

أجريــت هـذه الدراســة لتحديــد مــدى انتشــار بعـض مســبات الامــراض البكتيربــة فـى

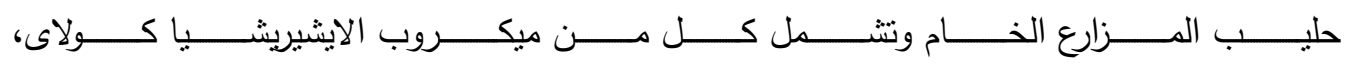

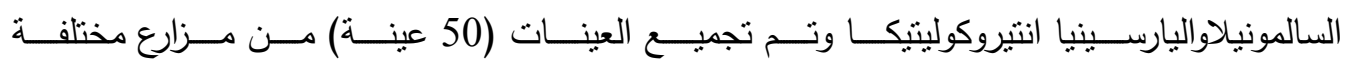

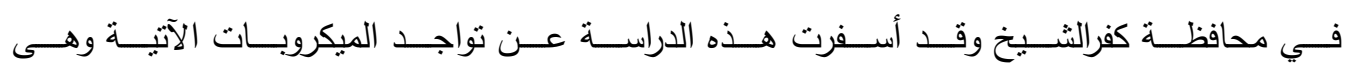

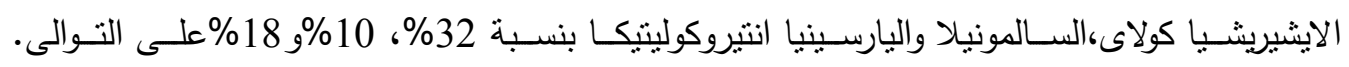

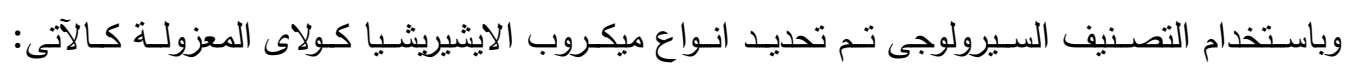
$\operatorname{EPEC}\left(\mathrm{O}_{114}: \mathrm{H}_{21}\right) ; \operatorname{ETEC}\left(\mathrm{O}_{125}: \mathrm{H} 21 \mathrm{andO}_{127}: \mathrm{H}_{6}\right) ; \mathrm{EHEC}\left(\mathrm{O}_{26}: \mathrm{H}_{11}\right.$ andO $\left._{111}: \mathrm{H}_{4}\right)$ بنسبة 50\%، 12.5\% و 37.5\% على التو الى. (S. Enteritidis) و وبالنسبة لميكروب السالمونيلا تم تصنيفها الى 40\% .

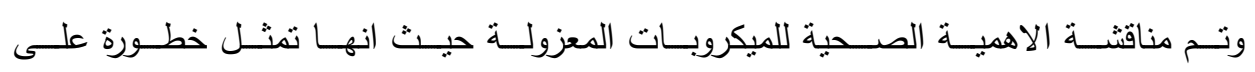

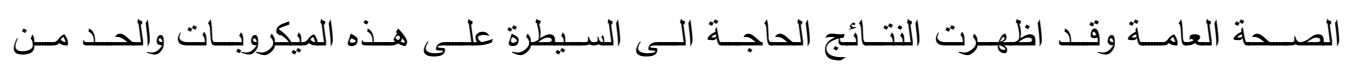
انتشارها فى الحليب الخام للحفاظ على صحة المستهلك. 